\title{
ACCUMULATION OF TRACE METALS IN THE MUSCLE, LIVER \\ AND GILLS TISSUES OF ARIUS MACULATUS AND PENNAHIA \\ ANEA FISH SPECIES FROM COASTAL WATERS, PENINSULAR MALAYSIA
}

Fathi, H. B.

Department of Animal production, Veterinary and Agriculture sciences faculty, Al-zawia University, Al-zawia, Libya

\section{ABSTRACT}

Fishes are considered as good indicators of trace metal pollution in the aquatic ecosystem in addition to being a good source of protein. Thus, the concentration of trace metals ( $\mathrm{Fe}, \mathrm{Zn}, \mathrm{Al}, \mathrm{As}, \mathrm{Cd}$ and $\mathrm{Pb}$ ) in water and muscle, liver and gills tissues of two important marine fish species, Arius maculatus and Pennahia anea collected from Kapar and Mersing in Peninsular Malaysia, were examined. Generally, Fe has the highest concentrations in both water and the fish species. While, $\mathrm{Cd}$ in both coastal waters showed high levels exceeding the international standards. The metal level concentrations in the fish samples are in the descending order from livers $>$ gills $>$ muscles. Fortunately, level of these metal concentrations in fish has not exceeded the permitted level of Malaysian and international standards.

Keywords: Trace metal, marine fishes, Kapar and Mersing, Peninsular Malaysia.

\section{INTRODUCTION:}

It is well documented that trace metals contamination could have devastating effects on the ecological balance of the recipient environment via altering the diversity of aquatic organisms especially to the fish community (Kamaruzzaman, 2011).

Fish enjoys agood reputation as a nutritious and healthy food and therefore consumption of which is recommended because it is a good source of omega-3 fatty acids which have been associated with positive health impacts like their cardio-protective effects (Castro-Gonzalez and MendezArmenta 2008).

Although fish consumption provides many benefits for cardiovascular health, there is agrowing concern that metals accumulated in fish muscle tissues may represent ahigher health risk than ahealth benefit, especially for populations with high fish consumption rates (Burger et al 2011). For instance, metals like $\mathrm{Fe}$ and $\mathrm{Zn}$ are essential for fish metabolism while some others such as $\mathrm{Al}, \mathrm{Cd}, \mathrm{As}$ and $\mathrm{Pb}$ are readily transferred through food chains and they are harmful for human when ingested over along time period (Çelik and Oehlenschlāger, 2007).

Fayoum J. Agric. Res. \& Dev., Vol. 29, No.2, July, 2014 
Fathi, H. B.

The fish tissues most commonly studied are muscles, livers, and gills, due to their different roles in the bioaccumulation processes. Gills and liver of fish are chosen as target organ for assessing metal accumulation.

The concentrations of metals in gills reflect the concentrations of metals in waters where the fish species live, whereas the concentrations in liver represent storage of metals. Although muscle is not an active tissue for accumulating the trace metals (Yilmaz, 2003), the study of potential metal accumulation in the muscle because it is the edible part of the fish for humans. Moreover, fishes are at the end of the aquatic food chain and may accumulate metals and pass them on to human beings when consumed as food, causing chronic or acute diseases (Burger and Gochfeld, 2007).

The marine ecosystem of Kapar is stressed due to its location in the Strait of Malacca where many pollution sources spread around this area. The Straits of Malacca is subjected to a great variety of pollutants due to its strategic location as amajor international shipping lane and the concentration of agriculture, industrialization, and urbanization activities along the coast of Peninsular Malaysia (Abdullah et al., 1999).

Besides the mentioned pollution sources, an electric power station that uses coal and discharges the polluted, pre-used water into the surface water systems surrounding Kapar may contribute to the trace metal pollution of the marine ecosystem in this area. Moreover, Kapar has great importance for the local fishery industry.

Therefore, estimation of the selected metals in fish of the marine coastal water of Kapar is necessary to define the current trace metal levels in the fish as well as to monitor the trends of change in fish trace metal levels with time. However, evaluation of the levels of the same metals in Mersing allows for comparison between the two areas, particularly in terms of the kinds and effects of different pollution sources in the two areas.

In the present study, the concentration of selected metals: iron $(\mathrm{Fe})$, zinc $(\mathrm{Zn})$, aluminum $(\mathrm{Al})$, arsenic $(\mathrm{As})$, cadmium $(\mathrm{Cd})$ and lead $(\mathrm{Pb})$ were determined in water and (muscles, livers, and gills) of two marine fish species to assess the status of trace metal pollution in two coastal waters in Malaysia.

\section{MATERIALS AND METHODS:}

Water and fish samples (Arius maculatus and Pennahia anea) were collected at two different stations of coastal waters of Peninsular Malaysia in November 2009 (Fig.1).

First sampling station was Kapar ( $3^{\circ} 11^{\prime} 54$ N, 101 $32^{\prime} 66$ E) located in Selangor on the west coast of Peninsular Malaysia near the Sultan Salahuddin Abdul Aziz Power Plant station. The second sampling station was Mersing $\left(2^{\circ} 25^{\prime} 60 \mathrm{~N}, 103^{\circ} 49^{\prime} 60 \mathrm{E}\right)$ in Johor Bahru on the west coast of Peninsular Malaysia. A bout $200 \mathrm{ml}$ of water collected using automated water sampler (21 cc capacity). Samples were stored in amber-coloured polyethylene

Fayoum J. Agric. Res. \& Dev., Vol. 29, No.2, July, 2014 
ACCUMULATION OF TRACE METALS IN THE MUSCLE...........

bottles pre-washed with $1(\mathrm{~N}) \mathrm{HNO}_{3}$ and deionised water. Fresh fish samples of each species from each station were collected from local fishermen.

The samples were kept in acool box $\left(4 \mathrm{C}^{\circ}\right)$ and transported to the laboratory for metal analysis. Total length $(\mathrm{cm})$ and weight $(\mathrm{g})$ of the fish samples were measured before dissection. Muscle, liver and gills were taken and dried until constant weight was obtained. The dried samples were digested in triplicate in amicrowave oven digestive system (Start D Microwave Digestive System). Analytical blanks were run in the same way as the samples and determined using standard solutions prepared in the same acid matrix.

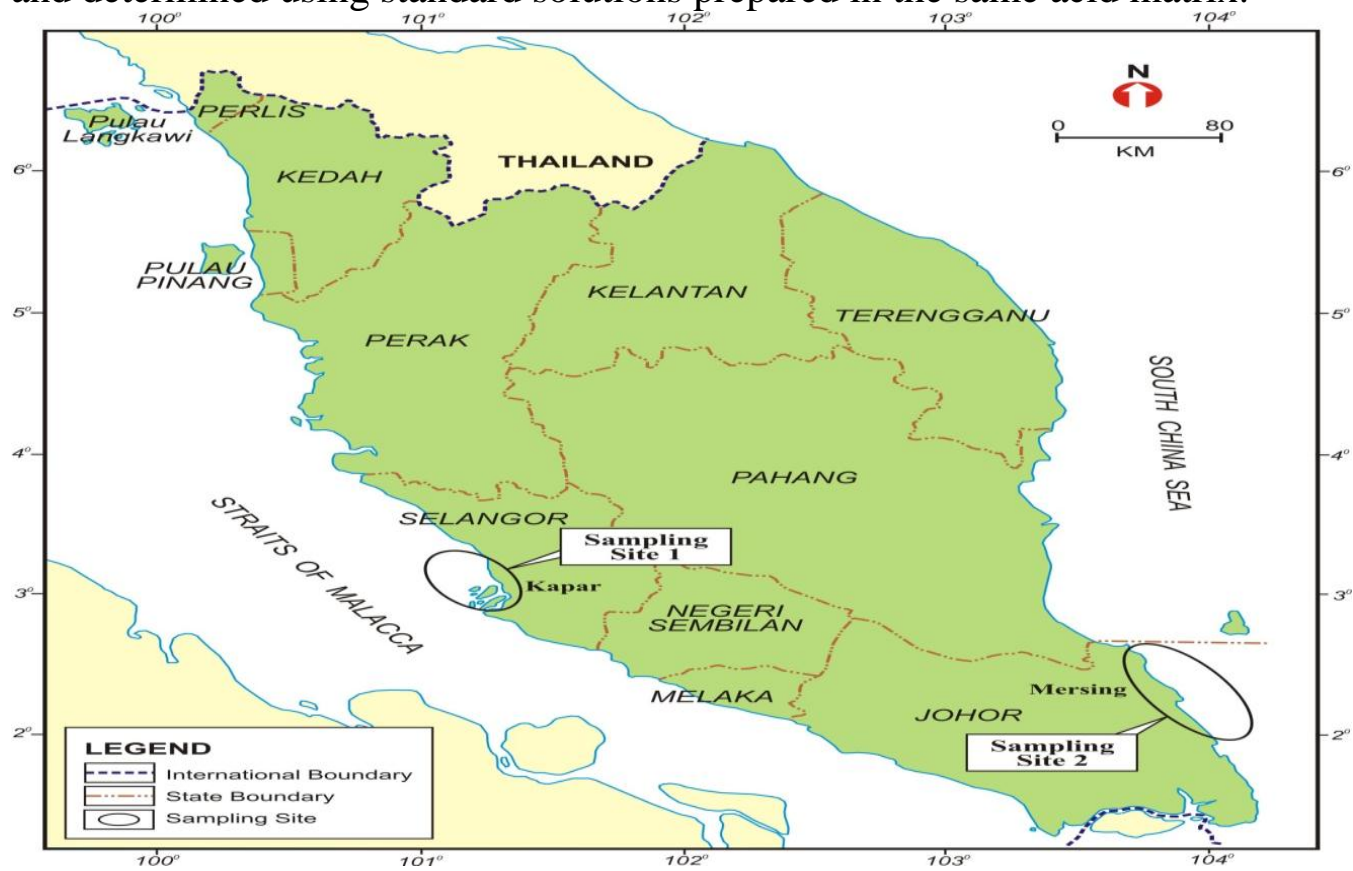

Figure 1 Locations of the sampling sites:

The concentrations of $\mathrm{Fe}, \mathrm{Zn}, \mathrm{Al}, \mathrm{As}, \mathrm{Cd}$ and $\mathrm{Pb}$ in water and two fish species were analyzed using inductively coupled plasma-mass spectrometry (ICP-MS, Perkin Elmer, Model Elan 9000, USA).

The results were expressed in micrograms of metal per gram fish on a dry weight basis ( $\mu \mathrm{g} / \mathrm{g}$ dry weight).

The performance of the method was evaluated by analyzing a standard reference material of marine biota sample (SRM2976, freeze-dried mussel tissue, National Institute of Standards and Technology, USA).

Recoveries for all metals studied were between $83 \%$ and $109 \%$ of the certified value (Table 1 ).

Due to the lack of normal distribution of data, the log transformation was implemented for the normalization process.

To examine the vital differences in the concentrations of heavy metals in the two research sites, the t-test was conducted. Moreover to investigate the

Fayoum J. Agric. Res. \& Dev., Vol. 29, No.2, July, 2014 
Fathi, H. B.

denoting dissimilarity of concentrations of trace metals among the three fish organs, the Kruskal-Wallis test was used.

For which a $P$ value less than 0.05 was considered as suggestive of statistical significance. All statistical tests were performed with SPSS 2010.

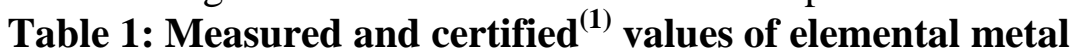
concentrations $\mu \mathrm{g} / \mathrm{g}$ dry weight \pm SD.

\begin{tabular}{|c|c|c|c|}
\hline Metal & Certified value & Measured value & Recovery (\%) \\
\hline $\mathrm{Fe}$ & $158 \pm 8$ & $144.6 \pm 7.1$ & 92.6 \\
\hline $\mathrm{Al}$ & $134 \pm 34$ & $128.2 \pm 12$ & 96.8 \\
\hline $\mathrm{Zn}$ & $137 \pm 13$ & $115.2 \pm 10$ & 84.4 \\
\hline $\mathrm{As}$ & $13.3 \pm 1.8$ & $14.5 \pm 0.9$ & 109 \\
\hline $\mathrm{Cd}$ & $0.82 \pm 0.16$ & $0.68 \pm 0.02$ & 83.7 \\
\hline $\mathrm{Pb}$ & $1.19 \pm 0.18$ & $1.03 \pm 0.04$ & 86.8 \\
\hline
\end{tabular}

(1) Certified mussel standard reference material (SRM) 2976.

\section{RESULTS AND DISCUSSION}

\section{Trace metals in water:}

Table 2 shows the trace metal levels in the seawater samples from Kapar and Mersing. The maximum concentration of the metals in the water samples in the descending order were $\mathrm{Fe}>\mathrm{Al}>\mathrm{As}>\mathrm{Zn}>\mathrm{Pb}>\mathrm{Cd}$ and $\mathrm{Fe}>$ $\mathrm{As}>\mathrm{Cd}>\mathrm{Zn}>\mathrm{Al}>\mathrm{Pb}$ from Kapar and Mersing respectively. $\mathrm{Al}, \mathrm{Zn}$ and As were higher concentration in Kapar, in the contrary, Fe and Cd were higher in Mersing.

The results represent that all the metals concentrations were below the maximum acceptable concentration, except for $\mathrm{Cd}$.

Table 2 Trace metal concentrations in Sea water from Kapar and

Mersing (mg/L):

\begin{tabular}{|l|l|c|c|c|c|c|c|}
\hline \multirow{2}{*}{} & \multicolumn{7}{|c|}{ Metals } \\
\cline { 2 - 8 } & & $\mathrm{Al}$ & $\mathrm{Fe}$ & $\mathrm{Zn}$ & $\mathrm{As}$ & $\mathrm{Pb}$ & $\mathrm{Cd}$ \\
\hline Kapar & Mean & 0.045 & 0.33 & 0.021 & 0.036 & 0.010 & 0.01 \\
\hline & Max & 0.046 & 0.34 & 0.033 & 0.040 & 0.014 & 0.011 \\
\hline & Min & 0.044 & 0.32 & 0.015 & 0.020 & 0.020 & 0.010 \\
\hline Mersing & Mean & 0.011 & 0.36 & 0.015 & 0.030 & 0.010 & 0.019 \\
\hline & Max & 0.012 & 0.40 & 0.016 & 0.033 & 0.014 & 0.030 \\
\hline & Min & 0.010 & 0.32 & 0.014 & 0.028 & 0.002 & 0.011 \\
\hline NWQSM* & & 0.5 & 1 & 0.4 & 0.1 & 0.5 & 0.01 \\
\hline WHO** & & - & - & 5 & 0.01 & 0.01 & 0.003 \\
\hline
\end{tabular}

Trace metals in various organs in fish:

Levels of six metals in muscle, liver and gill tissues of two fish species are shown in Tables 3 and 4.

In general, the highest concentrations of $\mathrm{Fe}, \mathrm{Zn}, \mathrm{Al}, \mathrm{As}$ and $\mathrm{Pb}$ were found in the liver tissues of both examined fish species. The concentrations of

Fayoum J. Agric. Res. \& Dev., Vol. 29, No.2, July, 2014 
ACCUMULATION OF TRACE METALS IN THE MUSCLE...........

the studied metals decreased following the order $\mathrm{Fe}>\mathrm{Zn}>\mathrm{Al}>\mathrm{As}>\mathrm{Pb}>\mathrm{Cd}$ in the two species. Iron exhibited the highest concentrations in all the examined organs of both species, followed by $\mathrm{Zn}$. On the other hand, the levels of $\mathrm{Pb}$ and $\mathrm{Cd}$ were generally the lowest. Similar findings were reported by many researchers (Dural et al., 2007; Tepe et al., 2007 and Turkmen et al., 2008).

It is observed that Fe concentration was the highest in both species and both studied areas. In the present study, with the exception of $\mathrm{Al}$, liver had significantly $(\mathrm{P} \leq 0.05)$ higher trace metal concentrations than gills and muscle. It is observed that, the mean concentrations of metals in the muscle, liver and gills of each fish species showed great variations, this may be related to the differences in ecological needs, swimming behaviors and the metabolic activities among different fish species.

The differences in metal concentrations of the tissues might be due to their capacity to induce metal-binding proteins such as metallothioneins. The present study showed that metal levels in liver and gills were highest in the studied species.

Its well known that large amount of metallothioneins induction occurs in the liver tissue of fish. The adsorption of metals on to gill surface could also be an important influence in total metal levels of the gill (Roesijadi and Robinson 1994).

The mean concentrations of $\mathrm{Fe}$ in the muscles of $A$. maculatus and $P$. anea and in Kapar were $53.84 \mu \mathrm{g} / \mathrm{g}$ and $34.91 \mu \mathrm{g} / \mathrm{g}$, respectively. However, in Mersing the mean concentrations were $21.62 \mu \mathrm{g} / \mathrm{g}$ in $A$. maculates and $21.47 \mu \mathrm{g} / \mathrm{g}$ in $P$. anea. It is revealed that Fe concentrations varied significantly $(\mathrm{P}<0.05)$ between the two stations.

Higher Fe concentration in muscle of both species was found in the fish of Kapar than that of Mersing. Kapar area is impacted by various sources of pollution such as electrical power station, international shipping activities, and urban and agricultural activities, amongst others. Similarly, the concentrations of $\mathrm{Fe}$ in the liver tissues of $\boldsymbol{P}$. anea and $\boldsymbol{A}$. maculatus in Kapar were approximately $1976.0 \mu \mathrm{g} / \mathrm{g}$ and $1008.0 \mu \mathrm{g} / \mathrm{g}$, respectively whereas in the same tissues of the fish from Mersing the concentrations were $526.0 \mu \mathrm{g} / \mathrm{g}$ and $924.6 \mu \mathrm{g} / \mathrm{g}$, respectively. The levels of $\mathrm{Fe}$ in the muscles of Mediterranean Sea fish that were reported in the literature range from 59.6 and $73.4 \mu \mathrm{g} / \mathrm{g}$ (Kalay and Canli, 2000). The concentrations of $\mathrm{Fe}$ in the fish muscle were reported to have the range of $24.1-50.3 \mu \mathrm{g} / \mathrm{g}$ in Parangipettai Coast, India (Raja et al., 2009) and the range of 49.9-889 $\mu \mathrm{g} / \mathrm{g}$ in the Turkish seas (Tepe et al., 2008). Therefore, the levels of Fe in fish muscles reported by the current study are generally in agreement with the literature.

According to the results obtained in Tables 3 and 4, concentrations of $\mathrm{Zn}$ in the livers of $\boldsymbol{P}$. anea and A. maculatus collected from Kapar and

Fayoum J. Agric. Res. \& Dev., Vol. 29, No.2, July, 2014 
Fathi, H. B.

Mersing were $114.1 \mu \mathrm{g} / \mathrm{g}$ and $555.9 \mu \mathrm{g} / \mathrm{g}$ (Table 3), and $104.8 \mu \mathrm{g} / \mathrm{g}$ and 341.9 $\mu \mathrm{g} / \mathrm{g}$ (Table 4), respectively. Generally, High concentrations of $\mathrm{Zn}$ were observed in the livers of $\boldsymbol{A}$. maculatus in both studied areas. Different levels of the investigated metals were detected in different species and even within the same species. It is observed that $\mathrm{Zn}$ concentration was the highest after $\mathrm{Fe}$ in both species and studied areas. The mean concentrations of $\mathrm{Zn}$ in the muscle tissues of $\boldsymbol{P}$. anea and A. maculatus collected from Kapar were around $26.3 \mu \mathrm{g} / \mathrm{g}$ and $51.0 \mu \mathrm{g} / \mathrm{g}$, respectively.

Table 3: Trace metal concentrations (Mean \pm SD) in muscle, liver and gills tissues of $A$. maculatus and $P$. anea fish from the coastal waters of Kapar, Malaysia:

\begin{tabular}{|c|c|c|c|c|c|c|c|}
\hline Species & Organ & \multicolumn{7}{|c|}{ Metals } \\
\hline & & Fe & Al & Zn & As & Cd & Pb \\
\hline Amaculatus & Muscle & $53.84 \pm 5.1$ & $7.24 \pm 0.0$ & $50.99 \pm 5.34$ & $12.58 \pm 0.8$ & $0.088 \pm 0.01$ & $0.12 \pm 0.01$ \\
\hline & Liver & $1007.1 \pm 11.7$ & $28.38 \pm 1.92$ & $550.89 \pm 6.8$ & $14.17 \pm 1.03$ & $1.01 \pm 0.07$ & $1.54 \pm 0.19$ \\
\hline & Gills & $805.6 \pm 3.38$ & $538.6 \pm 3.48$ & $840.89 \pm 5.2$ & $13.59 \pm 0.69$ & $0.048 \pm 0.01$ & $2.03 \pm 0.05$ \\
\hline P. anea & Muscle & $21.62 \pm 4.7$ & $3.00 \pm 0.11$ & $26.32 \pm 1.6$ & $3.28 \pm 0.65$ & $0.048 \pm 0.01$ & $0.13 \pm 0.004$ \\
\hline & Liver & $1975.0 \pm 38.9$ & $13.72 \pm 1.12$ & $114.11 \pm 2.2$ & $11.75 \pm 0.13$ & $0.694 \pm 0.05$ & $0.57 \pm 0.03$ \\
\hline & Gills & $891.6 \pm 28.6$ & $299.5 \pm 0.75$ & $60.21 \pm 0.44$ & $4.75 \pm 0.65$ & $0.690 \pm 0.05$ & $0.26 \pm 0.02$ \\
\hline WHO* & & 50 & - & 150 & 0.02 & 0.2 & 0.2 \\
\hline FAO** & & - & - & $30-100$ & $7.88^{\mathrm{a}}$ & 0.2 & $0.5-0.6$ \\
\hline MFR*** & & - & - & 100 & - & 1 & 2 \\
\hline
\end{tabular}

* WHO (1989)/** FAO (1992) / a FAO 1983 /***Malaysian Food regulation(1985)/No is the number fish samples.

However, in Mersing the respective concentrations were $18.1 \mu \mathrm{g} / \mathrm{g}$ and $25.4 \mu \mathrm{g} / \mathrm{g}$. Higher $\mathrm{Zn}$ concentrations in the muscle tissues of both species were found in Kapar than in Mersing.

The observed differences can be explained by the fact that the concentrations of these metals depend to a great extent on species, sex, biological cycle, and on the part of the fish analyzed (Tuzen, 2003).

Moreover, ecological factors such as season, location/environment of development, nutrient availability, temperature and salinity of the water may contribute to variations in the metal concentrations in fish.

Ranges of $\mathrm{Zn}$ concentrations reported earlier in the muscles and livers of Malaysian marine fish were 15.4-60.1 $\mu \mathrm{g} / \mathrm{g}$ and $27.1-95.3 \mu \mathrm{g} / \mathrm{g}$, respectively (Agusa et al., 2005). Another study conducted in Langkawi Island showed that all species had higher concentrations of $\mathrm{Zn}$ than of other metals and that the concentrations in muscles ranged from $34.3 \mu \mathrm{g} / \mathrm{g}$ to 49.4 $\mu \mathrm{g} / \mathrm{g}$ (Irwandi and Farida., 2009). Accordingly, the Zn concentrations in the

Fayoum J. Agric. Res. \& Dev., Vol. 29, No.2, July, 2014 
ACCUMULATION OF TRACE METALS IN THE MUSCLE...........

fish muscles detected by the present study are similar to those reported by Irwandi and Farida (2009).

In the present study, $\mathrm{Al}$ concentrations were the highest in the gills and ranged from $13.7 \mu \mathrm{g} / \mathrm{g}$ in $\boldsymbol{P}$. anea to $538.6 \mu \mathrm{g} / \mathrm{g}$ in $\boldsymbol{A}$. maculatus in Kapar and

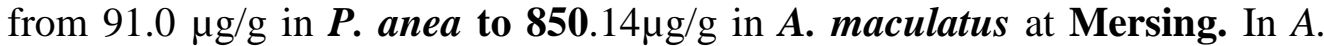
maculatus, the Al concentration was $7.2 \mu \mathrm{g} / \mathrm{g}$ in muscle and $28.4 \mu \mathrm{g} / \mathrm{g}$ in liver at Kapar station, whereas it was $5.4 \mu \mathrm{g} / \mathrm{g}$ and $10.0 \mu \mathrm{g} / \mathrm{g}$ in the fish muscle and liver tissues, respectively at Mersing station.

On the other hand, the concentrations of $\mathrm{Al}$ in the muscle and liver tissues of $\boldsymbol{P}$. anea was $3.0 \mu \mathrm{g} / \mathrm{g}$ and $13.7 \mu \mathrm{g} / \mathrm{g}$, respectively in Kapar, while the respective concentrations in Mersing were $1.5 \mu \mathrm{g} / \mathrm{g}$ and $5.1 \mu \mathrm{g} / \mathrm{g}$, respectively. The mean $\mathrm{Al}$ concentrations were higher in the three organs of fish species captured from Kapar than its concentration in the same organs of the fish species collected from of Mersing except gills of $\boldsymbol{A}$. maculatus from Mersing.

Table 4: Trace metal concentrations (Mean \pm SD) in muscle, liver and gills tissues of $A$. maculatus and $P$. anea fish species from the Mersing coastal waters, Malaysia:

\begin{tabular}{|l|c|c|c|c|c|c|c|}
\hline Species & Organ & \multicolumn{7}{|c|}{ Metals } \\
\hline & & Fe & Al & Zn & As & Cd & Pb \\
\hline A.maculatus & Muscle & $34.91 \pm 1.74$ & $5.44 \pm 1.25$ & $25.39 \pm 0.71$ & $14.2 \pm 2.34$ & $0.02 \pm 0.03$ & $0.2 \pm 0.02$ \\
\hline & Liver & $924.6 \pm 24.7$ & $10.05 \pm 1.7$ & $341.9 \pm 3.35$ & $21.89 \pm 0.9$ & $2.075 \pm 0.1$ & $0.87 \pm 0.07$ \\
\hline & Gills & $822.76 \pm 9.9$ & $850.1 \pm 7.1$ & $246.55 \pm 7.4$ & $7.65 \pm 0.1$ & $0.02 \pm 0.01$ & $0.24 \pm 0.02$ \\
\hline P. anea & Muscle & $21.47 \pm 1.86$ & $1.46 \pm 13$ & $18.1 \pm 0.79$ & $3.76 \pm 0.2$ & $0.023 \pm 0.3$ & $0.17 \pm 0.05$ \\
\hline & Liver & $525.96 \pm 17$ & $5.13 \pm 0.65$ & $104.84 \pm 1.23$ & $8.38 \pm 0.22$ & $2.46 \pm 0.02$ & $1.07 \pm 0.07$ \\
\hline & Gills & $461.4 \pm 8.6$ & $91.03 \pm 2.7$ & $66.24 \pm 1.3$ & $4.88 \pm 0.13$ & $0.05 \pm 0.01$ & $1.96 \pm 0.16$ \\
\hline WHO* & & 50 & - & 150 & 0.02 & 0.2 & 0.2 \\
\hline FAO** & & - & - & $30-100$ & $7.88^{\mathrm{a}}$ & 0.2 & $0.5-0.6$ \\
\hline MFR*** & & - & - & 100 & - & 1 & 2 \\
\hline
\end{tabular}

* WHO (1989)/** FAO (1992) / a FAO 1983 /***Malaysian Food regulation (1985).

The $\mathrm{Al}$ concentrations were reported to fall within the range 1.50-4.50 $\mu \mathrm{g} / \mathrm{g}$ in fish muscles from the Parangipettai Coast, India (Raja et al., 2009). On the other hand, the Al concentrations were reported earlier to fall in the range of $51.9-166.3 \mu \mathrm{g} / \mathrm{g}$ in muscles and in the range of $229.01-1412.7 \mu \mathrm{g} / \mathrm{g}$ in gills of Malaysian marine fish from Kapar (Mohamed et al., 2006).

As such, the $\mathrm{Al}$ concentrations observed in this study generally agree with the values reported in the literature.

Arsenic levels in the muscles of the analyzed fish ranged from $3.8 \mu \mathrm{g} / \mathrm{g}$ in $\boldsymbol{P}$. anea in Kapar to $14.2 \mu \mathrm{g} / \mathrm{g}$ in $\boldsymbol{A}$. maculatus in Mersing. As to fish livers, were ranged from $11.8 \mu \mathrm{g} / \mathrm{g}$ in $\boldsymbol{P}$. anea from Kapar to $21.9 \mu \mathrm{g} / \mathrm{g}$ in $A$. maculatus from Mersing. As regards fish gills, As levels were ranged from 4.9 $\mu \mathrm{g} / \mathrm{g}$ in $P$. anea from Mersing to $13.6 \mu \mathrm{g} / \mathrm{g}$ in A. maculatus from Kapar

Fayoum J. Agric. Res. \& Dev., Vol. 29, No.2, July, 2014 
Fathi, H. B.

(Tables 3 and 4). There are very few data about As levels in fish tissues from Malaysia against which to compare the levels of As found in this study.

According to published literature, ranges of As concentrations reported earlier in the muscles of Malaysian marine fish were $1.05-2.14 \mu \mathrm{g} / \mathrm{g}$ (Titik Budiatic, 2010).

Another study conducted showed that, As content of fish from India coastal waters was within the range of 0.01-0.63 $\mu \mathrm{g} / \mathrm{g}$ (Aditi Deshpande et al., 2008) which are levels well below the As levels detected in fish tissues by the current study.

In the present study, $\mathrm{Pb}$ concentrations in muscles ranged from 0.1 $\mu \mathrm{g} / \mathrm{g}$ in $P$. anea in Kapar to $0.2 \mu \mathrm{g} / \mathrm{g}$ in A. maculatus in Mersing while for livers the concentrations ranged from $1.1 \mu \mathrm{g} / \mathrm{g}$ in $P$. anea from Mersing to 1.5 $\mu \mathrm{g} / \mathrm{g}$ in A. maculatus in Kapar. On the other hand, the concentration ranged in gills from $1.96 \mu \mathrm{g} / \mathrm{g}$ in $P$. anea in Mersing to $2.03 \mu \mathrm{g} / \mathrm{g}$ in A. maculatus in Kapar. $\mathrm{Pb}$ levels were reported earlier in the literature to fall in the range of $0.018-0.023 \mu \mathrm{g} / \mathrm{g}$ for muscles and $0.115-0.380 \mu \mathrm{g} / \mathrm{g}$ for livers of fish from Mersing, and in the range of $0.026-0.72 \mu \mathrm{g} / \mathrm{g}$ for muscles and $0.041-0.872$ $\mu \mathrm{g} / \mathrm{g}$ for livers of fish from Langkawi coastal waters of Malaysia (Agusa et al., 2005). Hence, the $\mathrm{Pb}$ concentrations reported herein comply with these ranges.

The results of this investingation showed $\mathrm{Cd}$ levels did not significantly vary, $(\mathrm{P} \leq 0.05)$, the highest concentrations were observed in the livers of the fish species from Mersing, were the mean $\mathrm{Cd}$ concentration were ranged from $2.075 \mu \mathrm{g} / \mathrm{g}$ for livers of $\boldsymbol{A}$. maculatus to $2.458 \mu \mathrm{g} / \mathrm{g}$ for the same organs of $P$. anea from Mersing coastal water. While the highest levels of $\mathrm{Cd}$ in the muscles were recorded as $0.088 \mu \mathrm{g} / \mathrm{g}$ in muscles of $\boldsymbol{A}$. maculatus from Kapar, in the contrary, the lowest value of Cd detected was $0.021 \mu \mathrm{g} / \mathrm{g}$ in the muscles of $P$. anea from Mersing. Cd levels were reported in the literature to fall in the range of $0.14-0.57 \mu \mathrm{g} / \mathrm{kg}$ and $0.15-0.52 \mu \mathrm{g} / \mathrm{kg}$ for muscles of $A$. maculatus and $P$. anea from the same studied area Kapar (Mohamed et al., 2006). Another study was conducted on commercial marine fish from Klang Valley, Malaysia, concluded that the mean $\mathrm{Cd}$ concentrations in the fish muscles ranged from $0.121 \mathrm{mg} / \mathrm{kg}$ to $1.594 \mathrm{mg} / \mathrm{kg}$ (Nor Hasyimah et al., 2011).

Furthermore, Irwandi and Farida 2009 investigated on marine fin fish captured from the coast of Langkawi Island in Malaysia and reported that the mean $\mathrm{Cd}$ concentrations in the fish muscles ranged from $0.30 \mu \mathrm{g} / \mathrm{g}$ to 0.90 $\mu \mathrm{g} / \mathrm{g}$. Compared with the literature from different Malaysian marine coastal waters, our results for $\mathrm{Cd}$ concentration is lower than that reported in the literature. Cadmium and $\mathrm{Pb}$ have higher tendencies to bioaccumulate in the fish liver tissues which are involve in the detoxification process.

Fayoum J. Agric. Res. \& Dev., Vol. 29, No.2, July, 2014 
ACCUMULATION OF TRACE METALS IN THE MUSCLE...........

The presence of free protein-thiol group content and metallothioneins binding proteins in the liver forms strong fixation with the trace metals (Iwegbue, 2008). Meanwhile fish liver acts as major site for homeostasis (Reynders et al., 2006).

The variability in trace metal levels in different species depends on feeding habits, ecological needs, metabolism, age, size, length of the fish and fish habitat (Canli and Atli, 2003).

Concentrations of trace metals detected in the muscle, gill and liver samples indicate different bioaccumulation potentials. Muscles seem to be a transitory tissue in the pathway of metal uptake and in metal storage, and liver appears to be the tissue specialized in metal storage and detoxification (Kotze et al., 1999).

The gills comprise the chief exposure tissue and early uptake site of the soluble, waterborne metals in which metal concentrations are the highest in the early stages of exposure before these metals are transported to other fish tissues (Jezierska and witeska, 2001).

Although human activity is concentrated in the west coast of Peninsular Malaysia compared with the east coast, there is heavy contamination with trace metals in the east coast.

The results of the present study suggest that some point sources of trace metal contamination are present in the east coast of Peninsular Malaysia in spite of the relatively low human activities there.

\section{Conclusion:}

The highest metal concentrations were found in the fish liver and gill tissues, while the muscles tended to accumulate relatively low metal levels. Generally, the Fe concentrations were the highest in water and all organs of the two studied species in both studied areas, except the muscles of $\boldsymbol{P}$ anea from Kapar which had higher $\mathrm{Zn}$ concentration, and the gills of $\boldsymbol{A}$. maculatus from both Kapar and Mersing had higher $\mathrm{Al}$ and $\mathrm{Zn}$ levels, respectively. Moreover, the A. maculatus species had higher metal concentrations than the $P$ anea. The mean concentrations of trace metals analyzed in the muscles of both species were lower than the permissible limits.

Moreover, $\mathrm{Cd}$ concentrations in water samples in both sites exceed the international standard.

\section{Acknowledgements:}

The authors are grateful to the Libyan Ministry of High Education for the generous financial support they kindly provided for this study.

\section{REFERENCES:}

Abdullah, A.R., Tahir, N.M., Loong, T.S., Hoque, T.M. and Sulaiman, A.H., 1999. The GEF/UNDP/IMO Malacca Straits Demonstration Project: sources of pollution. Marine Pollution Bulletin, 39: 229233.

Fayoum J. Agric. Res. \& Dev., Vol. 29, No.2, July, 2014 
Fathi, H. B.

Aditi Deshpande, Sandeep Bhendigeri, Tejas Shirsekar, Dhanashri Dhaware, and Khandekar, R.N. 2008. "Analysis of heavy metals in marine fish from Mumbai Docks," Environ Monit Assess, 159: (1-4) 493-500.

Agusa, T., Kunito, T., Yasunaga, G., Iwata, H., Subramanian, A., Ismail, A. and Tanabe, S. 2005. Concentrations of trace elements in marine fish and its risk assessment in Malaysia. Marine Pollution Bulletin 51, 896-911.

Burger, j., Gochfeld, M., Jeitner, C., Burke, S., and Stamm, T. 2011 "Metal levels in flathead sole (Hippoglossoides elassodon) and great sculpin (Myoxocephalus polyacanthocephalus) from Adak Island, Alaska: potential risk to predators and fishermen,." Environ. Res., 103: 62-69.

Canli, M. and Atli, G. 2003. "The relationships between heavy metal $(\mathrm{Cd}$, $\mathrm{Cr}, \mathrm{Cu}, \mathrm{Fe}, \mathrm{Pb}, \mathrm{Zn}$ ) Levels and the size of six Mediterranean fish species.." Environmental Pollution 121: 129-136.

Castro-Gonzalez, M. I. and Mendez-Armenta, M. 2008. "Heavy metals: implications associated to fish consumption," Environmental Toxicology and Pharmacology, 26: 263-271.

Çelik, U. and Oehlenschläger, J. 2007. High Contents of Cadmium, Lead, Zinc and Copper in Popular Fishery Products Sold in Turkish Supermarkets. Food Control 18(3): 258-261.

Dural, M., Goksu, M. Z. I. and Ozak, A. A. 2007. "Investigation of heavy metal levels in economically important fish species captured from the Tuzla lagoon,"Food Chemistry 102: 415-421.

Irwandi, J. and Farida, O. 2009. "Mineral and heavy metal contents of marine fin fish in Langkawi Island, Malaysia ," International Food Research Journal 16: 105-112.

Iwegbue, C. M. A. 2008. "Heavy metals composition of livers and kidneys of cattle from southern Nigeria," Veterinarski Arhiv, vol. 78, no. 5, pp. 401-410.

Jezierska, M and Witeska, L.M. 2001 "Metal toxicity to fish. University of Podlasie," Monografic No. 42,.

Kalay, M. and Canli, M. 2000. Elimination of Essential $(\mathrm{Cu}, \mathrm{Zn})$ and Nonessential $(\mathrm{Cd}, \mathrm{Pb})$ Metals from Tissue of a Freshwater Fish Tilapia Zillii Following an Uptake Protocol. Tukr. J. Zool 24: 429436.

Kamaruzzaman, B. Y., Rina, Z., Akbar John, B. A. and Jalal, K. C. A. 2011. "Heavy Metal Accumulation in Commercally Important Fishes of South West Malaysian Coast," Reaesrch Journal of Environmental Sciences 10, 157-161.

Kotze, P., Preez, H. H., and Van Vuren, J. H. J. . 1999. Bioaccumulation of

Fayoum J. Agric. Res. \& Dev., Vol. 29, No.2, July, 2014 
ACCUMULATION OF TRACE METALS IN THE MUSCLE........... 11 Copper and Zinc in Oreochromis Mossambicus and Clarias Gariepinus, from the Olifants River, Mpumalanga, South Africa. Water SA, 25: 99-100.

Mohamed, C. A. R., Samat, A., Otman, M. R. and Muda, W. M. 2006. Kandungan $\mathrm{Cd}, \mathrm{Cr}, \mathrm{Fe}, \mathrm{Mn}$ dan $\mathrm{Al}$ di dalam ikan di persekitaran stesen janakuasa electric, TNB, kapar, Selangor, Malaysia. Journal of Analytical Sciences, 10(1): 87-92.

Nor Hasyimah, A.K., James Noik, V., Teh, Y.Y., Lee, C.Y and Pearline Ng, H.C. 2011. Assessment of cadmium $(\mathrm{Cd})$ and lead $(\mathrm{Pb})$ levels in commercial marine fish organs between wet markets and supermarkets in Klang Valley, Malaysia. International Food Research Journal 18: 770-777.

Raja, P., Veerasingam, S., Suresh, G., Marichamy, G. and Venkatachalapath, R. 2009. "Heavy metals concentration in four commercially valuable marine edible fish species from Parangipettai coast, south east coast of India," International Journal of Animal and Veterinary Advances 1: (1) 10-14.

Roesijadi, G. and Robinson, W. E. 1994. Metal regulation in aquatic animals: mechanisms of uptake, accumulation and release. in: aquatic toxicology, molecular, biochemical and cellular perspectives. Malins, D. C and Ostrander, G.K, Eds. CRC Press, Boca Raton, FL, USA: 387-420.

Tepe, Y., Türkmen, M. and Türkmen, A. 2008. Assessment of Heavy Metals in Two Commercial Fish Species of four Turkish Seas. Environmental Monitoring and Assessment 146(1-3): 277-284.

Titik Budiati, 2010. "The Presence of Arsenic as Heavy Metal Contaminant on Salmon : a Risk Assessment," International Journal of Basic \& Applied Sciences IJBAS-IJENS, 10, No. 05, pp. 6-12,

Tüzen, M. 2003. Determination of Heavy Metals in Fish Samples of the Middle Black Sea (Turkey) by Graphite Furnace Atomic Absorption Spectrometry. Food Chemistry 80(1): 119-123.

Yilmaz, A. B. 2003. Levels of Heavy Metals (Fe, $\mathrm{Cu}, \mathrm{Ni}, \mathrm{Cr}, \mathrm{Pb}$, and $\mathrm{Zn}$ ) in Tissue of Mugil cephalus and Trachurus mediterraneus from Iskenderun Bay, Turkey. Environmental Research, 92(3): 277-281.

Fayoum J. Agric. Res. \& Dev., Vol. 29, No.2, July, 2014 
Fathi, H. B.

تراكم المعادن النادرة فى الأنسجة العضلية والكبدية والخيشومية لنوعى الأسماك المصادة من مياه Pennahia anea

فتحي الهاشمي بشير- قسم الانتاج الحيواني- كلية البيطرة والعلوم الزراعية - جامعة الزاوية-ليبيا

تعتبر الأسماك مؤشرا جيدا على تلوث النظام المائى بالمعادن النادرة بالإضافة إلى أنها مصدر هام للبروتين. لذلك تم إختبار تركيز كل من المعادن (الحديد - الزنك - الألمونيوم - الزرنيخ

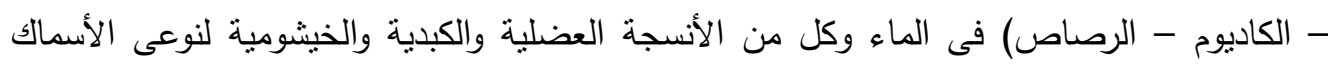
Pennahia anea و Arius maculates تقع على السواحل الماليزية.

بشكل عام، كان لمعدن الحديد أعلى تركيز فى كل من الماء نوعي الاسماك التى تم دراستهما، بينما أظهر معدن الكاديوم فى كل من مياه سواحل المنطقتين مسنويات عالية تفوق الحدود

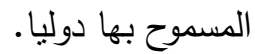

كانت مستويات تركيز المعادن فى عينات الأسماك فى ترنيب تنازلى من حيث التركيز من

الكبد > الخياشيم > العضلات. ولحسن الحظ كان تركيز هذه المعادن المدروسة فى عينات الأسماك لركال أقل من الحدود المسموح بها محليا فى ماليزيا وعالميا.

Fayoum J. Agric. Res. \& Dev., Vol. 29, No.2, July, 2014 